\title{
Methods Of Use Of An Online Economics Textbook
}

Jon R. Miller, University of Idaho, USA

Lori Baker-Eveleth, University of Idaho, USA

\begin{abstract}
The rising cost of college textbooks over the last decade provides an opportunity for alternatives. Electronic or online textbooks are an effective substitute to the traditional paper-based textbooks, although students have been slow to transition to the new method. A custom, professor-written online textbook not only addresses the reduction in cost, but also creates a better connection to the material in the course and allows for frequent updates and error corrections. Issues related to reading an online textbook are explored and evidence of methods of student use of the text is provided.
\end{abstract}

Keywords: distributed technologies, economic environment, information economy, online behavior, licensing

\section{INTRODUCTION}

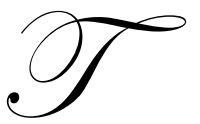

he rising cost of hard copy textbooks is causing students to consider electronic alternatives to traditional textbooks. According to the U.S. Government Accountability Office (2005), between 1987 and 2004, the average price of a college textbook increased twice as fast as the consumer price index - an average of 6\% per year. On average, a college textbook costs $\$ 125$ with many texts not resalable on the used textbook market. The total textbook cost for a typical year of classes is close to $\$ 1,000$ (Christopher, 2008; and Rampell, 2008). This increased cost creates financial pressure for college students and their families. Students, parents, state legislatures, federal agencies, university bookstores, and book publishers have responded to rising textbook costs by making it an important and controversial issue on college campuses (Chaker, 2006; Editorial, 2005; Kang, 2004; Kingsbury \& Galloway, 2006; and Roberts, 2006).

In addition to rising monetary textbook costs, the relationship between a textbook and its course can result in frictions which lead to non-monetary opportunity cost. If a textbook is purchased, a student wants to feel like it will be used. What happens when the course outline doesn't match the text or doesn't explain some of the material? In a traditional introductory course, such as economics or management, the text often doesn't flow with the desired course outline. Typical introductory textbooks have a tendency to be big and encyclopedic (Siegfried et al., 1991). Introductory history textbooks often present historical knowledge as conclusions without exhibiting the research and deliberation embedded in the conclusions (Voelker, 2008). Without a connection between the course and the textbook, students may decide not to purchase the textbook.

Traditional hard copy textbooks from publishers are limited in how quickly they can correct errors or make updates to the textbook (Larson, 2002 and Stewart, 2009). This is especially problematic in some dynamic fields, such as information systems or technology, where the rate of change in material is very rapid, or in economics where events such as the recent financial crisis change the nature of fiscal and monetary policy. The length of time to correct errors is usually dependent on the publisher for revisions. Therefore, mistakes in a textbook can take three or four years to correct. In addition, to save money, cost-conscious students might purchase an older edition of a book, not realizing errors are present. Some of these problems can be lessened if publishers adopt the use of a companion website, which is used (among other things) to highlight errors discovered after the book was published. It is not as good as a new revision, but it is fast and doesn't require the long waiting period for the new edition to be published. By contrast, custom online texts can be revised easily and posted to a website in a timely fashion. 
A variety of proposals have been offered to address textbook cost, such as using an extensive electronic materials library, free e-books, textbook rentals, and advertising-supported books (Blumenstyk, 2008; Christopher, 2009; King, 2009; Kingsbury \& Galloway, 2006; and Rampell, 2008). One alternative, and our focus here, is the use of a custom, professor-written online text. The institutional context for the text is a residential-based, medium-sized, four-year university. The text was developed for - and used in - an introductory economics course where students had access to the text on the course website. A student could access the textbook by downloading the complete text to a computer, printing if desired, or reading the document online.

Providers of electronic content access are experimenting with different, lower-cost text pricing models. Some are free, while others have a quarterly or semester fee, or request a donation to a cause/program (Beezer, 2009; Rampell, 2008; and Stewart, 2009). A new digital publisher, Flat World Knowledge (n.d.), is providing interactive, electronic material and is providing it free of charge in a time-limited, online-only format. Other versions of the text, including a bound print format, are available for a fee. The University of Phoenix consolidated all course textbooks in an electronic library, charging $\$ 75$ a semester for electronic access to any textbook (Blumenstyk, 2008). Open source programs, such as GNU Free Documentation License (GFDL), allow the authors of the content as well as readers, to make suggestions and note errors and corrections (Beezer 2009). Safari Books Online (Safari Books Online Index) allows students to electronically access many online books and other learning materials, including searching, browsing, copying, saving and printing parts of the materials.

The next section presents some advantages of online texts. We then discuss the emerging literature about online textbooks, and the transition to reading online. Information on how students read a custom professor-written online text is presented next. Finally, we offer some concluding comments and suggestions for future research.

\section{ADVANTAGES OF ONLINE TEXTS}

The textbook serves an important purpose in the classroom particularly when average class sizes are over 60 students. A challenge in large classes is the ability of the instructor to answer students' questions (Sweeney, Siegfried, Raymond, \& Wilkinson, 1983). Due to the ratio of one faculty member to many students, often students need to acquire additional content and clarification outside of the classroom from different sources such as textbooks. With a variety of content access methods available-traditional hard copy textbooks, electronic textbooks, web-based materials and web-search engines-there are additional opportunities to reach students outside of the classroom and increase the understanding of and engagement with class material (Johnson \& Harroff, 2006; Rampell, 2008). Different learning styles also suggest that providing different ways of accessing classroom content is advantageous for learning (Dorn, 2007; Huon, Spehar, Adam, \& Rifkin, 2007).

Changing the mechanism for reading textbooks (to electronic) allows an environment where students can interact and engage with the material in a different way. Most digital books are searchable, can be highlighted like a traditional textbook, and often have a comment box or annotation ability on the pages (Ravid, 2008). Many technologies being used in education can be used to enhance students' ability to interact and collaborate with other students as well as the professor (Contreras-Castillo, Favela, Perez-Fragoso, \& Santamaria-del-Angel, 2004; Hall andGraham, 2004; Paxhia, 2008). Web 2.0 technologies like blogs or wikis allow students to create and co-create content about various topics. Blogs are similar to a paper-based diary where students can journal, reflect, and express their opinions. Wikis on the other hand are much like an encyclopedia where permissions are given to edit descriptions of events or topics (Alexander, 2006). This shift in content development moves away from the traditional textbook publishers and instead to faculty, instructors and students (Ravid, 2008).

These tools can be used to enhance the learning experience. Electronic content is easier to find in an online environment (like Blackboard or Moodle) where students can link to the material. Discussion of the material, particularly if the content is controversial or debatable, engages students more in the material (Conole, Dyke, Oliver, \& Seale, 2004; Soekijad, Veld, \& Enserink, 2004). Orrill (2000) classifies these types of interactions as learning objects, where knowledge is co-constructed by those interacting with the material based on authentic problems and issues, increasing the motivation to learn. Learning objects are advantageous because of the portability to other learning environments (Koper \& Manderveld, 2004). One-time use objects, such as standard hard copy textbooks, are limited in portability. 
In spite of advantages in terms of cost, timeliness of corrections and changes, and multiple methods of displaying content, the shift to electronic material has been slow. The lack of comfort reading from the computer has slowed the acceptance of electronic textbooks (Carlson, 2005; Nelson, 2008). Eye strain from a computer screen and back and neck problems are a concern (Crawford, 2006). Although new electronic readers such as Amazon's Kindle have improved the ability to read electronic textbooks, students were "trained" to use traditional textbooks (Carlson, 2005). Many students want to be able to pick up the textbook as needed, as opposed to being tethered to a computer.

Resistance to electronic texts might be waning, however. The rising cost of tuition and the recent economic downturn will likely have an effect on colleges and universities in the future (Debolt, 2008). An increase in tuition will influence students when they purchase their textbooks. Cech (2008) suggests that students facing rising costs may soon be willing to switch methods. Computer ownership, the Internet, social networking, and short text messaging have become ubiquitous on college campuses (Ellison, Steinfield, \& Lampe, 2007). Their acceptance of various communication devices and technology creates the possible impetus for change in college textbooks. In the next section, we discuss the method students used to access an online text in multiple course sections.

\section{METHOD OF USING A CUSTOM, PROFESSOR-WRITTEN ONLINE TEXT}

While the discussion of electronic presentation alludes to the difficulty of the method and the slowness of technological adoption, no hard data exists on these phenomena. In the following, we present information that is one, albeit limited, attempt to shed light on this issue.

Five times in a five year period we queried students in an introductory economics course about their satisfaction with the text as a learning tool and how they read it. The data on method of reading the text is our focus here. We used a short, anonymous questionnaire administered moments before the in-person final exam. The response rate was nearly $100 \%$. In all cases, the voluntary nature of the response, anonymity and confidentiality were offered and strictly enforced. These results appear in Table 1.

Table 1: How Students Read the Custom, Professor-Written Online Text

\begin{tabular}{|l|c|c|c|c|c|}
\hline \multicolumn{1}{|c|}{ Term } & n & $\begin{array}{c}\text { Printed } \\
\text { text }\end{array}$ & $\begin{array}{c}\text { Downloaded to computer and read } \\
\text { from screen }\end{array}$ & $\begin{array}{c}\text { Read online } \\
\text { only }\end{array}$ & $\begin{array}{c}\text { Mixed use, print and } \\
\text { electronic }\end{array}$ \\
\hline Fall 2005 & 102 & $59(58 \%)$ & $15(15 \%)$ & $15(15 \%)$ & $13(13 \%)$ \\
\hline Spring 2006 & 110 & $67(61 \%)$ & $13(12 \%)$ & $12(11 \%)$ & $9(16 \%)$ \\
\hline Spring 2009 & 62 & $29(47 \%)$ & $12(19 \%)$ & $12(19 \%)$ & $9(15 \%)$ \\
\hline Fall 2009 & 65 & $31(48 \%)$ & $8(12 \%)$ & $12(20 \%)$ & $12(20 \%)$ \\
\hline Spring 2010 & 70 & $27(39 \%)$ & $14(20 \%)$ & $17(24 \%)$ & $12(17 \%)$ \\
\hline
\end{tabular}

Our results confirm the suggestions in the literature about resistance to reading from a computer screen. Depending on the semester, between $39 \%$ and $61 \%$ of the students printed the text and read the hard copy version. Another $13 \%$ to $20 \%$ had mixed use, with some combination print and electronic reading. Between $23 \%$ and $44 \%$, again depending on the semester, read in electronic form only. While five data points are insufficient to measure a trend in any statistical sense, the 2010 respondents did more true electronic reading than their 2005 counterparts, perhaps suggesting increased acceptance of electronic methods over time. We must caution, however, the course in which the text is used is currently an online course, and over time we might have less computer oriented students selecting out of the course.

\section{CONCLUSION AND FUTURE RESEARCH}

We are now in the fifth year of use of a custom, professor-written online text in an introductory economics course. The online textbook has reduced textbook cost, both monetary and non-monetary, performed well (in the opinion of students) as a learning tool; but it has not been read by the majority of students only in an electronic form. Our results confirm, on a very limited scale, the reluctance to read texts electronically mentioned in the emerging literature. Continued research will help to determine whether the trend in electronic reading is upward, in our specific context, and why electronic textbook reading is not growing more rapidly, in general, in an era where print 
newspapers are contracting daily. We currently are engaged in a university-wide study of the determinants of adoption and use of electronic text methods on our campus and await other studies on other campuses and in other online learning environments.

\section{AUTHOR INFORMATION}

Jon R. Miller received his B.A. in economics from Pacific Lutheran University in 1970, and AM and PhD degrees in economics from Washington University in 1971 and 1974, respectively. He taught at Clarkson College (19741977), University of Utah (1977-89), and since 1989 has been Professor of Economics at the University of Idaho (UI). Professor Miller has published in the American Economic Review, American Journal of Agricultural Economics, Journal of Environmental Economics and Management, and the Annals of Regional Science, among other journals. In 2008, he received the First Interstate Bank Excellence in Teaching Award at the UI.

Lori Baker-Eveleth (Ph.D. Washington State University) is an Associate Professor of Information Systems at the University of Idaho since 2002. Her research interests include computer-mediated communication, virtual teams, and technology and user acceptance. Recent publications include the Journal of Information Systems Education, EDUCAUSE, Behaviour \& Information Technology, Journal of Informatics Education Research, Journal of Business and Management, and the Journal of Education for Business.

\section{REFERENCES}

1. Alexander, B. (2006). Web 2.0: A new wave of innovation for teaching and learning. Learning, (41)2, 32.

2. Balas, J. L. (2006). Are e-books finally poised to succeed? Computers in Libraries, 26(10), 34-36.

3. Beezer, R. (2009). The truly free textbook. EduCause Review, 44(1), $23-24$.

4. Blumenstyk, G. (2008, June 13). To cut costs, ought colleges look to for-profit models? Chronicle of Higher Education, pp. A19-20.

5. Carlson, S. (2005, February 11). Online textbooks fail to make the grade. Chronicle of Higher Education, A35-36.

6. $\quad$ Cech, S. J. (2008, July 30). Textbooks moving into cyberspace. Education Week, 27, 6.

7. Chaker, A.M. (2006, September 28). Efforts mount to cut costs of textbooks: As prices rise at twice the rate of inflation, states pass laws to encourage cheaper alternatives. The Wall Street Journal, D 1-3.

8. Christopher, L. C. (2009). Academic Publishing: Digital alternatives to expensive textbooks, Seybold Online, 8, 11-14.

9. College Textbooks: Enhanced Offerings Appear to Drive Recent Price Increases: GAO-05-806. (2005). Government Accountability Office.

10. Conole, G., Dyke, M., Oliver, M., \& Seale, J. (2004). Mapping pedagogy and tools for effective learning design. Computers \& Education, 43(1-2), 17-33.

11. Contreras-Castillo, J., Favela, J., Perez-Fragoso, C., \& Santamaria-del-Angel, E. (2004). Informal interactions and their implications for online courses. Computers \& Education, 42(2), 149-168.

12. Crawford, W. (2006, October). Why aren't ebooks more successful? EContent, 29, 44.

13. Debolt, D. (2008). Tuition at American Colleges Rose Moderately. Chronicle of Higher Education, 26.

14. Dorn, R. I. (2007). Online versus hardcopy textbooks. Science, 315(5816), 1220.

15. Editoral (2005, September 6). High book prices reason to rebel. Spokesman Review, B 4.

16. Ellison, N. B., Steinfield, C., \& Lampe, C. (2007). The Benefits of Facebook "Friends:' Social Capital and College Students' Use of Online Social Network Sites. Journal of Computer-Mediated Communication, 12(4), 1143-1168.

17. FlatWorld Knowledge. (n.d.). Retrieved March 15, 2010 from FlatWorld Knowledge: http://www.flatworldknowledge.com/.

18. Hall, H. \& Graham, D. (2004). Creation and recreation: motivating collaboration to generate knowledge capital in online communities. International Journal of Information Management, 24(3), 235-246.

19. Huon, G., Spehar, B., Adam, P., \& Rifkin, W. (2007). Resource use and academic performance among first year psychology students. Higher Education, 53, 1-27.

20. Johnson, C., \& Harroff, W. (2006). The new art of making books. Library Journal, 131(Spring Supplement), 8-12. 
21. Kang, S. (2004, August 24). New options for cheaper textbooks: Under fire for high prices, publishers push alternatives; renting your chem book. The Wall Street Journal, D 1.

22. King, P. (2009, April 23). A textbook case of renting books. The Wall Street Journal, B 1.

23. Kingsbury, A., \& Galloway, L. (2006, October 16). Textbooks enter the digital era. U.S. News and World Report, 141, 63-65.

24. Koper, R., \& Manderveld, J. (2004). Educational modelling language and learning design: new opportunities for instructional reusability and personalised learning. British Journal of Educational Technology, 35(5), 537-551.

25. Larson, R. (2002). E-enabled textbooks: Lower cost, higher functionality, Campus Technology. Retrieved May 9, 2010 from http://campustechnology.com/articles/2002/05/eenabled-textbooks-lower-cost-higherfunctionality.aspx.

26. Nelson, M. R. (2008, November 28). Is higher education ready to switch to digital course materials? Chronicle of Higher Education, 55, A29.

27. Orrill, C. H. (2000). Learning objects to support inquiry-based online learning. Retrieved December, 4, 2008, from http://reusability.org/read/chapters/orrill.doc

28. Page-Thomas, K. (2006). Measuring task-specific perceptions of the world wide web. Behaviour \& Information Technology, 25(6), 469-477.

29. Paxhia, S. (2008, September 25). Interactive content: Bringing students and professors together. Paper presented at the Multimedia Educational Resource for Learning and Online Teaching (MERLOT) Conference Minneapolis, Minnesota.

30. Preece, J. (2000). Online communities: Designing usability, supporting sociability. New York: John Wiley $\&$ Sons, Inc.

31. Rampell, C. (2008, May 2). Free textbooks: An online company tries a controversial publishing model. Chronicle of Higher Education, pp. 14-15.

32. Ravid, G., Kalman, Y.M., \& Rafaeli, S. (2008). Wikibooks in Higher Education: Empowerment through Online Distributed Collaboration. Computers in Human Behavior, 24, 1913-1928.

33. Safari Books Online. (n.d.). Retrieved from Safari Books Online: http://www.safaribooksonline.com/Corporate/Index/.

34. Siegfried, J. J., Bartlett, R. L., Hansen, W. L., Kelley, A. C., McCloskey, D. N., \& Tietenberg, T. H. (1991). The status and prospects of the economics major. The Journal of Economic Education, 22(3), 197224.

35. Soekijad, M., Veld, M. A. A. H., \& Enserink, B. (2004). Learning and knowledge processes in interorganizational communities of practice. Knowledge and Process Management, 11(1), 3-12.

36. Stewart, R. (2009). Some thought on free textbooks. EduCause Review, 44(1), 24-26.

37. Sweeney, M. J., Siegfried, J. J., Raymond, J. E., and Wilkinson, J. T. (1983). The structure of the introductory economics course in United States Colleges. The Journal of Economic Education, 68-75.

38. Voelker, D. J. (2008). Assessing Student Understanding in Introductory Courses: A Sample Strategy. History Teacher, 41(4), 505-518. 
NOTES 